American Journal of Pharmacology and Toxicology 4 (1): 1-7, 2009

ISSN 1557-4962

(C) 2009 Science Publications

\title{
Analgesic and Antioxidant Activity of the Hydromethanolic Extract of Mikania scandens (L.) Willd. Leaves
}

\author{
${ }^{1}$ S.M. Raquibul Hasan, ${ }^{2}$ Mariam Jamila, ${ }^{1}$ Muntasir Mamun Majumder, \\ ${ }^{1}$ Raushanara Akter, ${ }^{1} \mathrm{Md}$. Mokarram Hossain, ${ }^{3} \mathrm{Md}$. Ehsanul Hoque Mazumder, \\ ${ }^{1} \mathrm{Md}$. Ashraful Alam, ${ }^{1}$ Rumana Jahangir, ${ }^{3} \mathrm{Md}$. Sohel Rana, ${ }^{4} \mathrm{Md}$. Arif and ${ }^{5}$ Shafiqur Rahman \\ ${ }^{1}$ Department of Pharmacy, Stamford University Bangladesh \\ ${ }^{2}$ Department of Pharmacy, Bangladesh University, Bangladesh \\ ${ }^{3}$ Department of Pharmacy, Jahangirnagar University, Bangladesh \\ ${ }^{4}$ Department of Biochemistry and Molecular Biology, University of Dhaka, Bangladesh \\ ${ }^{5}$ Department of Pharmaceutical Sciences, College of Pharmacy, \\ South Dakota State University, Brookings, SD 57007, USA
}

\begin{abstract}
Problem statement: Mikania scandens (L.) Willd., a medicinal plant, is popularly used as herbal remedy for various ailments in Bangladesh. But the scientific basis for its medicinal use especially in pain and inflammation remains unknown. Therefore, the present study was designed to evaluate analgesic and antioxidant potential of the hydromethanol extract of the leaves of the plant. Approach: The analgesic activity was determined for its central and peripheral pharmacological actions using hotplate and tail immersion method and acetic acid-induced writhing test in mice respectively. The hydromethanol extract was also investigated for its antioxidant action using 1,1diphenyl-2-picrylhydrazyl (DPPH) radical scavenging, Nitric Oxide (NO) scavenging and reducing power assays. Results: The extract, at the dose of 250 and $500 \mathrm{mg} \mathrm{kg}^{-1}$, produced a significant $(\mathrm{p}<0.05)$ increase in pain threshold in hotplate and tail immersion methods in a dose dependent manner. In acetic acid-induced writhing test, the extract $\left(500 \mathrm{mg} \mathrm{kg}^{-1}\right)$ produced a maximum of $53.73 \%$ inhibition $(\mathrm{p}<0.001)$ of writhing reaction compared to the reference drug Diclofenac-Na (76\%). A dose dependent scavenging of DPPH radical and NO was observed with good reducing power with the extract. In DPPH radical scavenging assay, the $\mathrm{IC}_{50}$ value of the extract was $375.40 \mu \mathrm{g} \mathrm{mL} L^{-1}$ while the $\mathrm{IC}_{50}$ value for the reference ascorbic acid was $55.89 \mu \mathrm{g} \mathrm{mL}{ }^{-1}$. The $\mathrm{IC}_{50}$ values of the extract and ascorbic acid were 220.43 and $125.10 \mu \mathrm{g} \mathrm{mL}^{-1}$, respectively in NO scavenging assay. Conclusion: The findings of the study suggested that the extract from Mikania scandens has strong analgesic and antioxidant effects.
\end{abstract}

Keywords: Ethnopharmacology, medicinal plant, analgesic, antioxidant, inflammation, tail immersion.

\section{INTRODUCTION}

Pain is a sensorial modality and primarily protective in nature, but often causes discomfort. It is the most important symptom that brings the patient to physician. Analgesics relieve pain as a symptom, without affecting its cause ${ }^{[1]}$. Currently available analgesic drugs such as opiates and NSAIDs are not useful in all cases due to their adverse effects. In this respect new compounds with improved pain management capacity and fewer side effects are being sought with urgency. Moreover, a number of pathologies are known to be ultimately associated with the imbalance of pro and antioxidant factors in living systems. Exogenous antioxidant compounds may therefore exert beneficial actions upon systems which have been deprived from sufficient amounts of endogenous antioxidants as in some cardiovascular diseases, tumors, inflammation, ulcer and aging $^{[2]}$. Currently, the possible toxicity of synthetic antioxidants has been criticized. Thus interest in natural antioxidant, especially of plant origin, has greatly increased in recent years ${ }^{[3]}$.

Mikania scandens (Family: Asteracae) is a twining herb with long-petioled, opposite leaves and small

Corresponding Author: Shafiqur Rahman, Department of Pharmaceutical Sciences, College of Pharmacy, South Dakota State University, Intramural Building, P.O. Box 2202C, Brookings, SD 57007, USA Tel: 605-688-4239 Fax: 605-688-5993 
homogamous flower-heads grows as a weed in all areas of Bangladesh ${ }^{[4]}$. Aqueous leaf extracts of this plant have been used in traditional/folk medicine to treat stomach ulcers and a variety of other diseases. In India, although the plant is consumed as a vegetable, it is thought to be efficacious in the treatment of gastric problems. The plant is a rich source of vitamin A and C and also contains vitamin B, Mikanin, friedelin, efifriedinol, some sesquiterpene, dilactones including mikanolide, dihydromikanolide, deoxymikanolide and scandenolide. Three deterpenic acids known as kaurenic acid, butyryloxykaurenic acid and benzoyloxykaurenic acid, stigmasterol and betasitosterin have also been isolated from this plant ${ }^{[4]}$. The plant is reported to have psychopharmacological and neuropharmacological properties; antimicrobial, antiinflammatory, antipyretic, ulcerprotective, anticarcinogenic activities ${ }^{[5-8]}$. But still no scientific and methodical investigation has so far been reported in literature regarding its analgesic and antioxidant action. Therefore, as a part of our ongoing phytochemical and pharmacological investigations on local medicinal plants of Bangladesh ${ }^{[9,10]}$, the present study has been designed to examine the analgesic and antioxidant activity of the hydromethanol extract of the leaves of Mikania scandens (L.) Willd.

\section{MATERIALS AND METHODS}

Chemicals and drugs: DPPH (1, 1-diphenyl, 2-picryl hydrazyl), was obtained from Sigma chemical co. USA. Ascorbic acid was obtained from SD Fine chem. Ltd., Biosar, India. Naphthyl ethylene diamine dihydrochloride was purchased from Roch-light Ltd., Suffolk, England. Sodium nitro prusside was obtained from Ranbaxy Lab., Mohali, India and potassium ferricyanide from May and Backer, Dagenham, UK. Diclofenac-Na was collected from Square Pharmaceuticals Ltd., Bangladesh and Nalbuphine was from Incepta Pharmaceuticals Ltd., Bangladesh.

Plant material: The whole plant with leaves, stems and roots was collected from Savar, Dhaka in February 2008 and was identified by Prof. Dr. Abdul Ghani, Stamford University Bangladesh. The plant was thoroughly washed with water; roots and stems were discarded and the leaves were dried in hot air woven at $55^{\circ} \mathrm{C}$ for 3 days and at $40^{\circ} \mathrm{C}$ for the next 4 days.

Extraction: The dried leaves were coarsely powdered and extracted with a mixture of methanol: water (7:3, $\mathrm{v} / \mathrm{v}$ ) by a Soxhlet apparatus at $50^{\circ} \mathrm{C}$. The solvent was completely removed and obtained dried crude extract which was used for investigation.
Animal: For the experiment Swiss albino mice of either sex, 3-4 weeks of age, weighing between 20-25 g, were collected from the animal research branch of the International Center for Diarrheal Disease and Research, Bangladesh (ICDDRB). Animals were maintained under standard environmental conditions (temperature: $\left(24.0 \pm 1.0^{\circ}\right)$, relative humidity: $55-65 \%$ and $12 \mathrm{~h} \mathrm{light} / 12 \mathrm{~h}$ dark cycle) and had free access to feed and water ad libitum. The animals were acclimatized to laboratory condition for one week prior to experiments. All protocols for animal experiment were approved by the institutional animal ethical committee.

Phytochemical screening: The freshly prepared crude extract was qualitatively tested for the presence of chemical constituents. Phytochemical screening of the extract was performed using the following reagents and chemicals: Alkaloids with Dragendorff's reagent, flavonoids with the use of $\mathrm{Mg}$ and $\mathrm{HCl}$; tannins with ferric chloride and potassium dichromate solutions and saponins with ability to produce stable foam and steroids with Libermann- Burchard reagent. Gum was tested using Molish reagent and concentrated sulfuric acid; reducing sugars with Benedict's reagent. These were identified by characteristic color changes using standard procedures ${ }^{[4]}$.

\section{Analgesic screening:}

Hot plate method: The animals were divided into four groups with five mice in each group. Group I animals received vehicle (1\% Tween 80 in water, $10 \mathrm{~mL} \mathrm{~kg}^{-1}$ body weight), animals of Group II received Nalbuphine at $10 \mathrm{mg} \mathrm{kg}^{-1}$ body weight while animals of Group III and Group IV were treated with 250 and $500 \mathrm{mg} \mathrm{kg}^{-1}$ body weight (p.o.) of the crude extract of M. scandens. The animals were placed on Eddy's hot plate kept at a temperature of $55 \pm 0.5^{\circ} \mathrm{C}$. A cut off period of $15 \mathrm{~s}$, was observed to avoid damage to the paw ${ }^{[11]}$. Reaction time was recorded when animals licked their fore or hind paws, or jumped prior to and 0, 30,60 and 90 min after oral administration of the samples ${ }^{[12-14]}$.

Tail immersion test: The procedure is based on the observation that morphine like drugs selectively prolongs the reaction time of the typical tail withdrawal reflex in mice ${ }^{[14]}$. The animals were treated as discussed above. From $1-2 \mathrm{~cm}$ of the tail of mice was immersed in warm water kept constant at $55^{\circ} \mathrm{C}$. The reaction time was the time taken by the mice to deflect their tails. The first reading was discarded and the reaction time was recorded as a mean of the next three readings. A latency period of $20 \mathrm{~s}$ was defined as complete analgesia and 
the measurement was then stopped to avoid injury to mice. The latent period of the tail-flick response was determined before and 0, 30, 60 and $90 \mathrm{~min}$ after the administration of drugs.

Acetic acid-induced writhing test: The analgesic activity of the samples was also studied using acetic acid-induced writhing model in mice. Test samples and vehicle were administered orally $30 \mathrm{~min}$ before intraperitoneal administration of $0.7 \%$ acetic acid but Diclofenac-Na was administered intraperitonially $15 \mathrm{~min}$ before injection of acetic acid. After an interval of $5 \mathrm{~min}$, the mice were observed for specific contraction of body referred to as 'writhing' for the next $10 \min ^{[15]}$.

\section{Tests for antioxidant activity:}

DPPH radical scavenging activity: The free radical scavenging activity of the extracts, based on the scavenging activity of the stable 1,1-diphenyl-2picrylhydrazyl (DPPH) free radical, was determined by the method described by ${ }^{[16]}$. Plant extract $(0.1 \mathrm{~mL})$ was added to $3 \mathrm{~mL}$ of a $0.004 \%$ methanol solution of DPPH. Absorbance at $517 \mathrm{~nm}$ was determined after $30 \mathrm{~min}$ and the percentage inhibition activity was calculated from $\left.\left(A_{0}-A_{1}\right) / A_{0}\right] \times 100$, where $A_{0}$ is the absorbance of the control and $A_{1}$ is the absorbance of the extract/standard. The inhibition curves were prepared and $\mathrm{IC}_{50}$ values were obtained by Probit analysis ${ }^{[17]}$.

Nitric oxide scavenging assay: Nitric oxide radical scavenging was estimated on the basis of Griess Illosvoy reaction using method followed by Govindarajan et al. ${ }^{[18]}$. In this investigation, GriessIllosvoy reagent was modified by using naphthyl ethylene diamine dihydrochloride $(0.1 \% \mathrm{w} / \mathrm{v})$ instead of 1-napthylamine $(5 \%)$. The reaction mixture $(3 \mathrm{~mL})$ containing sodium nitroprusside (10 mM, $2 \mathrm{~mL})$, phosphate buffer saline $(0.5 \mathrm{~mL})$ and $M$. scandens extract $\left(5-250 \mu \mathrm{g} \mathrm{mL}^{-1}\right)$ or standard solution (ascorbic acid, $0.5 \mathrm{~mL}$ ) was incubated at $25^{\circ} \mathrm{C}$ for $150 \mathrm{~min}$. After incubation, $0.5 \mathrm{~mL}$ of the reaction mixture mixed with $1 \mathrm{~mL}$ of sulfanilic acid reagent $(0.33 \%$ in $20 \%$ glacial acetic acid) and allowed to stand for $5 \mathrm{~min}$ for completing diazotization. Then, $1 \mathrm{~mL}$ of naphthyl ethylene diamine dihydrochloride was added, mixed and allowed to stand for $30 \mathrm{~min}$ at $25^{\circ} \mathrm{C}$. A pink coloured chromophore is formed in diffused light. The absorbance of these solutions was measured at $540 \mathrm{~nm}$ against the corresponding blank solutions.
Reducing power: The reducing power of $M$. scandens was determined according to method followed by Srinivas et $a l .^{[19]}$. Different concentrations of M. scandens extract (50-250 $\mu \mathrm{g})$ in $1 \mathrm{~mL}$ of distilled water were mixed with phosphate buffer $(2.5 \mathrm{~mL}$, $0.2 \mathrm{M}, \mathrm{pH} 6.6)$ and potassium ferricyanide $\left[\mathrm{K}_{3} \mathrm{Fe}(\mathrm{CN})_{6}\right]$ $(2.5 \mathrm{~mL}, 1 \%)$. The mixture was incubated at $50^{\circ} \mathrm{C}$ for $20 \mathrm{~min}$. A portion $(2.5 \mathrm{~mL})$ of trichloroacetic acid (10\%) was added to the mixture, which was then centrifuged at $3000 \mathrm{rpm}$ for $10 \mathrm{~min}$. The upper layer of the solution $(2.5 \mathrm{~mL})$ was mixed with distilled water $(2.5 \mathrm{~mL})$ and $\mathrm{FeCl}_{3}(0.5 \mathrm{~mL}, 0.1 \%)$ and the absorbance was measured at $700 \mathrm{~nm}$. Increased absorbance of the reaction mixture indicated increased reducing power. Ascorbic acid was used as the reference.

Statistical analysis: Statistical analysis for animal experiment was carried out using one-way ANOVA followed by Dunnet's multiple comparisons. The results obtained were compared with the vehicle control group. p-values $<0.05,0.001$ were considered to be statistically significant.

\section{RESULTS}

Phytochemical screening: Phytochemical analyses of the crude extract revealed the presence of flavonoid steroid, alkaloid, tannin, gum and saponin (Table 1).

\section{Analgesic screening:}

Hot plate method: Result of hotplate test is shown in Table 2. Both doses of the extract produced a dose dependent increase in latency time when compared with the vehicle. The result was found to be statistically significant $(\mathrm{p}<0.05-0.001)$.

Tail immersion test: The tail withdrawal reflex time following administration of the extract of $M$. scandens was found to increase with increasing dose of the sample. The result was statistically significant $(\mathrm{p}<0.05-$ 0.001 ) and was comparable to the reference drug Nalbuphine (Fig. 1).

Acetic acid-induced writhing test: Table 3 shows the effects of the extract of on acetic acid-induced writhing in mice. The oral administration of both doses of M. scandens extract significantly $(\mathrm{p}<0.001)$ inhibited writhing response induced by acetic acid in a dose dependent manner.

Table 1: Result of chemical group tests of the methanol extract of Mikania scandens

\begin{tabular}{lllllll}
\hline Extract & Steroid & Alkaloid & Reducing sugar & Tannin & Gum & Flavonoid \\
\hline ME of $M$. scandens & + & +++ & - & Saponin \\
\hline ME: & ++ & + & + & +++ & + & +
\end{tabular}


Am. J. Pharm. \& Toxicol., 4 (1): 1-7, 2009

Table 2: Effects of the hydromethanol extract of Mikania scandens on latency to hotplate test

\begin{tabular}{|c|c|c|c|c|c|c|c|c|}
\hline \multirow[b]{2}{*}{ Groups } & \multirow{2}{*}{$\begin{array}{l}\text { Dose } \\
\left(\mathrm{mg} \mathrm{kg}^{-1}\right)\end{array}$} & \multicolumn{4}{|c|}{ Mean latency (s) before and after drug administration } & \multicolumn{3}{|c|}{ Percentage of inhibition } \\
\hline & & $0 \mathrm{~min}$ & $30 \min$ & $60 \mathrm{~min}$ & $90 \mathrm{~min}$ & $30 \mathrm{~min}$ & $60 \mathrm{~min}$ & $90 \mathrm{~min}$ \\
\hline Group-I & Vehicle & $2.26 \pm 0.219$ & $2.45 \pm 0.225$ & $2.16 \pm 0.197$ & $2.58 \pm 0.261$ & - & - & - \\
\hline Group-II & 10 & $2.34 \pm 0.088$ & $5.62 \pm 0.624 * *$ & $7.97 \pm 0.649 * *$ & $11.67 \pm 0.1 .007 * *$ & 64.8 & 71.5 & 80.4 \\
\hline Group-III & 250 & $2.21 \pm 0.073$ & $3.27 \pm 0.264 *$ & $4.57 \pm 0.747 *$ & $4.30 \pm 0.383 *$ & 44.1 & 46.7 & 44.5 \\
\hline Group-IV & 500 & $2.07 \pm 0.217$ & $3.57 \pm 0.850 * *$ & $5.66 \pm 0.546^{* *}$ & $5.45 \pm 0.469 * *$ & 56.9 & 62.1 & 52.8 \\
\hline
\end{tabular}

Group I animals received vehicle (1\% Tween 80 in water), Group II received Nalbuphine $10 \mathrm{mg} \mathrm{kg}^{-1}$ body weight, Group III and Group IV were treated with 250 and $500 \mathrm{mg} \mathrm{kg}^{-1}$ body weight (p.o.) of the crude extract of M. scandens. Values are mean $\pm \mathrm{SEM},(\mathrm{n}=5)$; *: p<0.05, **: $\mathrm{p}<0.001$ dunnet test as compared to control

Table 3: Effects of the hydromethanol extract of Mikania scandens on acetic acid-induced writhing in mice

\begin{tabular}{llll}
\hline Groups & $\begin{array}{l}\text { Dose } \\
\left(\mathrm{mg} \mathrm{kg}^{-1}\right)\end{array}$ & No. of writhing & $\begin{array}{l}\text { Percentage } \\
\text { of protection }\end{array}$ \\
\hline Group-I & Vehicle & $40.2 \pm 1.271$ & - \\
Group-II & 10 & $10.4 \pm 0.940^{* *}$ & 76.13 \\
Group-III & 250 & $26.1 \pm .994^{* *}$ & 35.07 \\
Group-IV & 500 & $18.6 \pm 0.906^{* *}$ & 53.73 \\
\hline
\end{tabular}

Values are mean \pm SEM, $(\mathrm{n}=5) ; * * \mathrm{p}<0.001$, Dunnet test as compared to control. Group I animals received vehicle (1\% Tween 80 in water), Group II received Nalbuphine $10 \mathrm{mg} \mathrm{kg}^{-1}$ body weight, Group III and Group IV were treated with 250 and $500 \mathrm{mg} \mathrm{kg}^{-1}$ body weight (p.o.) of the crude extract of $M$. scandens

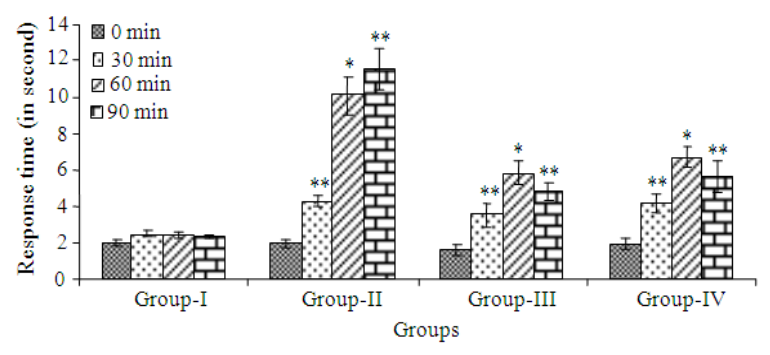

Fig. 1: Effects of the hydromethanol extract of Mikania scandens on tail withdrawal reflex of mice induced by tail immersion method. Values are mean \pm SEM, $(\mathrm{n}=5) ; *$ : $<0.05, * *: \mathrm{p}<0.001$, Dunnet test as compared to control. Group I animals received vehicle (1\% Tween 80 in water), Group II received Nalbuphine $10 \mathrm{mg} \mathrm{kg}^{-1}$ body weight, Group III and Group IV were treated with 250 and $500 \mathrm{mg} \mathrm{kg}^{-1}$ body weight (p.o.) of the crude extract of M. scandens

DPPH radical scavenging activity: The DPPH $(1,1-$ diphenyl-2-picrylhydrazyl) radical scavenging activity of M. scandens is shown in Fig. 2. This activity was found to increase with increasing concentration of the extract. DPPH antioxidant assay is based on the ability of 1, 1-diphenyl-2-picryl-hydrazyl (DPPH), a stable free radical, to decolorize in the presence of antioxidants. The DPPH radical contains an odd electron, which is responsible for the absorbance at 515-517 $\mathrm{nm}$ and also for a visible deep purple color.

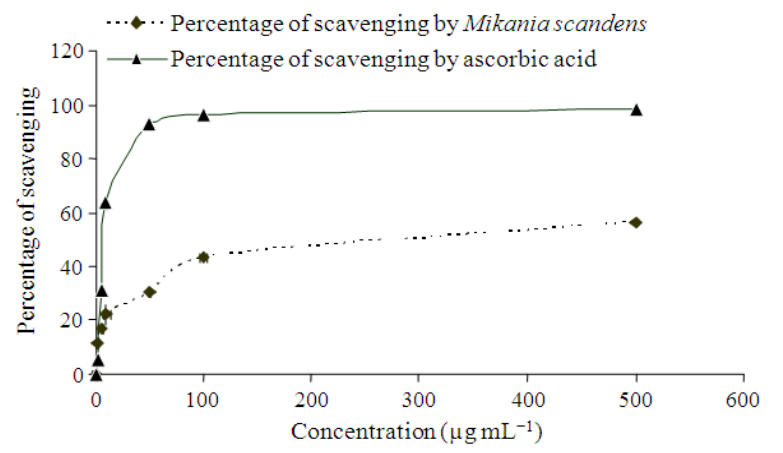

Fig. 2: DPPH radical scavenging activity of the hydromethanol extract Mikania scandens. Values are the average of duplicate experiments and represented as mean $\pm \mathrm{SD}$

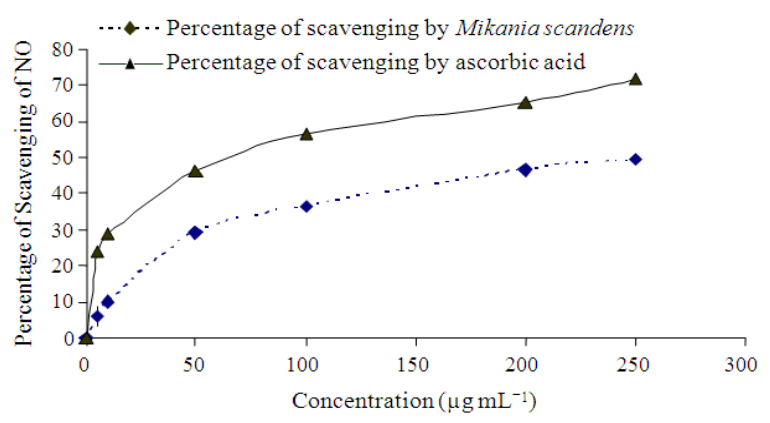

Fig. 3: Nitric oxide scavenging activity of the hydromethanol extract Mikania scandens. Values are the average of duplicate experiments and represented as mean $\pm \mathrm{SD}$

When DPPH accepts an electron donated by an antioxidant compound, the DPPH is decolorized, which can be quantitatively measured from the changes in absorbance. The $\mathrm{IC}_{50}$ value of the extract was $375.40 \mu \mathrm{g} \mathrm{mL}^{-1}$, as opposed to that of ascorbic acid $\left(\mathrm{IC}_{50}\right.$ $55.89 \mu \mathrm{g} \mathrm{mL}^{-1}$ ), which is a well known antioxidant.

Nitric oxide scavenging assay: The hydromethanol extract of the $M$. scandens exhibited dose dependent scavenging of nitric oxide (Fig. 3) with an $\mathrm{IC}_{50}$ value of $220.43 \mu \mathrm{g} \mathrm{mL}^{-1}$ compared to $125.10 \mu \mathrm{g} \mathrm{mL}^{-1}$ which was the $\mathrm{IC}_{50}$ value for the reference ascorbic acid. 


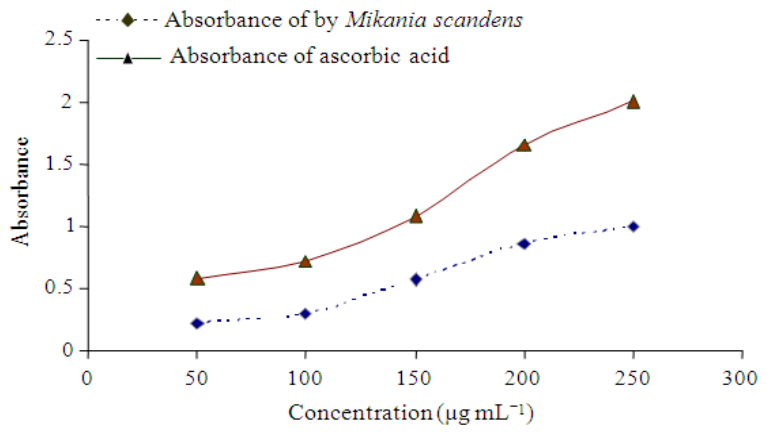

Fig. 4: Reducing power of the hydromethanol extract Mikania scandens. Values are the average of duplicate experiments and represented as mean $\pm \mathrm{SD}$

Reducing power: The hydromethanol extract displayed remarkable reducing power which was found to rise with increasing concentration as shown in Fig. 4.

\section{DISCUSSION}

The hotplate method and tail immersion test are considered to be selective to examine compounds acting through opoid receptor; the extract increased mean basal latency which indicates that it may act via centrally mediated analgesic mechanism. Narcotic analgesics inhibit both peripheral and central mechanism of pain, while non steroidal antiinflammatory drugs inhibit only peripheral pain ${ }^{[20,21]}$. The extract inhibited both mechanisms of pain, suggesting that the plant extract may act as a narcotic analgesic.

Acetic acid-induced writhing model represents pain sensation by triggering localized inflammatory response. Such pain stimulus leads to the release of free arachidonic acid from tissue phospholipid ${ }^{[22]}$. The acetic acid induced writhing response is a sensitive procedure to evaluate peripherally acting analgesics The response is thought to be mediated by peritoneal mast cells ${ }^{[23]}$, acid sensing ion channels ${ }^{[24]}$ and the prostaglandin pathways ${ }^{[25]}$.

Preliminary phytochemical screening reveals the presence of flavonoid steroid, alkaloid, tannin, gum and saponin in the plant extract. So, the observed analgesic activity may be attributed to these compounds. Moreover, recent studies suggest that the inflammatory tissue damage is due to the liberation of reactive oxygen species form phagocytes invading the inflammation sites ${ }^{[26]}$. There are also reports on the role of flavonoid, a powerful antioxidant ${ }^{[27,28]}$, in analgesic activity primarily by targeting prostaglandins ${ }^{[29,30]}$. There are also reports on the role of tannins in antinociceptive activity $^{[31]}$. Again the plant extract demonstrated good antioxidant action in the tested models. So it can be assumed that cyclooxygenase (COX) inhibitory activity together with antioxidant activity may reduce the production of free arachidonic acid from phospholipid or may inhibit the enzyme system responsible for the synthesis of prostaglandins and ultimately relive pain-sensation.

Polyphenolic compounds, like flavonoids, tannins and phenolic acids, commonly found in plants have been reported to have multiple biological effects, including antioxidant activity ${ }^{[27,28,32,33]}$. Flavonoids and tannins present in the plant extract, as evident from phytochemical screening, may be responsible for the antioxidant action. NO scavenging capacity of the extract may help to arrest the chain of reactions initiated by excess generation of $\mathrm{NO}$ that are detrimental to the human health. Nitric oxide is also implicated for inflammation, cancer and other pathological conditions ${ }^{[34]}$. A direct correlation between antioxidant capacity and reducing power of certain plant extracts has been reported ${ }^{[35]}$. The reducing properties are generally associated with the presence of reductones, which have been shown to exert antioxidant action by breaking the free radical chain by donating a hydrogen atom ${ }^{[36]}$. Therefore, antioxidants with free radical scavenging activities may have great relevance in the prevention and treatment of diseases associated with oxidants or free radicals ${ }^{[37]}$.

\section{CONCLUSION}

Based on the results of the present study, we conclude that the plant extract possesses strong analgesic and antioxidant potential. However, further studies are necessary to examine underlying mechanisms of analgesic and antioxidant effects and to isolate the active compound (s) responsible for these pharmacological activities.

\section{ACKNOWLEDGEMENT}

We express our sincere thanks and gratitude to Professor Dr. Abdul Ghani, Chairman, Department of Pharmacy, Stamford University, Bangladesh for providing laboratory facilities and necessary reagents support while doing the study.

\section{REFERENCES}

1. Mate, G.S., N.S. Naikwade, C.S.A.A. Chowki and S.B. Patil, 2008. Evaluation of anti-nociceptive activity of Cissus quadrangularis on albino mice. Int. J. Green Pharm., 2: 118-121. http://www.greenpharmacy.info/article.asp?issn=0 973-8258 
2. Halliwell, B. and J.M. Gurtteridge, 1990. Role of free dadicals and catalytic metal ions in human disease: An overview. Methods Enzymol., 186: 1-85. http://www.ncbi.nlm.nih.gov/pubmed/2172697

3. Jayaprakash, G.K. and L.J. Rao, 2000. Phenolic constituents from lichen Parmontrema stuppeum. (Nyl.) hale and their antioxidant activity. Z. Naturforsch., 55: 1018-1022. http://www.znaturforsch.com/ac/v55c/55c1018.pdf

4. Ghani, A., 2003. Medicinal Plants of Bangladesh. The Asiatic Society of Bangladesh. 2nd Revised Edn., Dhaka, Bangladesh, ISBN: 9845123481, pp: 603.

5. Ysrael, M.C. and K.D. Croft, 1990. Inhibition of leukotriene and platelet activating factor synthesis in leucocytes by the sesquiterpene lactone scandenolide. Planta Med., 56: 268-270. http://www.ncbi.nlm.nih.gov/pubmed/2168055

6. Bishayee, A. and M. Chatterjee, 1994. Protective effects of Mikania cordata root extract against physical and chemical factors-induced gastric erosions in experimental animals. Plants Med., 60: 110-113. DOI: $10.1055 / \mathrm{s}-2006-959428$

7. Bishayee A. and M. Chatterjee, 1994. Anticarcinogenic biological response of Mikania cordata: Refections in hepatic biotransformation systems. Cancer Lett., 81: 193-200. DOI: 10.1016/0304-3835(94)90202-X

8. Mosaddik, M.A. and K.M. Alam, 2000. The antiulcerogenic effect of an alkaloidal fraction from Mikania cordata on diclofenac sodium-induced gastrointestinal lesions in rats. J. Pharm. Pharmacol., 52: 1157-1162. DOI: 10.1211/0022357001774930

9. Alam, M.A., A. Ghani, N. Subhan, M.M. Rahman, M.S. Haque, M.M. Majumder, M.E.H. Mazumder, R.A. Akter, L. Nahar and S.D. Sarker, 2008. Antioxidant and membrane stabilizing properties of the flowering tops of Anthocephalus cadamba. Nat. Prod. Com., 3: 65-67. http://members.naturalproduct.us/Secure/Issue.aspx ?volumeissueid $=25$

10. Mazumder, M.E.H. and S. Rahman, 2008. Pharmacological evaluation of Bangladeshi medicinal plants for antioxidant activity. Pharm. Biol., $\quad 46: \quad 704-709 . \quad$ DOI: 10.1080/13880200802215735

11. Franzotti, E.M., C.V.F. Santos, H.M.S.L. Rodrigues, R.H.V. Mourao, M.R. Andrade and A.R. Antoniolli, 2000. Anti-inflammatory, analgesic activity and acute toxicity of Sida cordifolia L. (Malva-branca). J. Ethnopharmacol., 72: 273-278. DOI: $10.1016 / \mathrm{S} 0378-8741(00) 00205-1$
12. Eddy, N.B. and D. Leimback, 1953. Synthetic analgesic. II. Dithienyl butenylanddithienyl butylamines. J. Pharmacol. Exp. Ther., 107: 385-393. http://jpet.aspetjournals.org/cgi/reprint/107/3/385

13. Malairajan, P., G. Gopalakrishnan, S. Narasimhan and K. Jessi Kala Veni, 2006. Analgesic activity of some Indian medicinal plants. J. Ethnopharmacol., 106: 425-428. DOI: 10.1016/j.jep.2006.03.015

14. Toma, W., J.S. Graciosa, C.A. Hiruma-Lima, F.D.P. Andrade, W. Vilegas and A.R.M. Souza Brita, 2003. Evaluation of the analgesic and antiedematogenic activities of Quassia amara bark extract. J. Ethnopharmacol., 85: 19-23. DOI: 10.1016/S0378-8741(02)00334-3

15. Ahmed, F., M.S.T. Selim, A.K. Das and M.S.K. Choudhuri, 2004. Anti-inflammatory and antinociceptive activities of Lippia nodiflora Linn. Pharmazie, 59: 329-333. DOI: 10.5555/phmz.2004.59.4.329

16. Braca, A., N.D. Tommasi, L.D. Bari, C. Pizza, M. Politi and I. Morelli, 2001. Antioxidant principles from Bauhinia terapotensis. J. Natl. Prod., 64: 892-895. DOI: 10.1021/np0100845

17. Viturro, C., A. Molina and G. Schmeda-Hischmann, 1999. Free radical scavengers from Mutisia friesiana (asteraceae) and Sanicula graveolens (apiaceae). Phytother. Res., 13: 422-424. http://cat.inist.fr/?aModele=afficheN\&cpsidt=1950575

18. Govindarajan, R., S. Rastogi, M. Vijayakumar, A. Shirwaikar, A.K.S. Rawat, S. Mehrotra and P. Palpu, 2003. Studies on the Antioxidant Activities of Desmodium gangeticum. Biol. Pharm. Bull., 26: 1424-1427. DOI: 10.1248/bpb.26.1424

19. Srinivas, K., F.O. Jimoh, D.S. Grierson and A.J. Afolayan, 2007. Antioxidant activity of two steroid alkaloids extracted from Solanum aculeastrum. J. Pharmacol. Toxicol., 2: 160-167. http://scialert.net/pdfs/jpt/2007/160-167.pdf

20. Elisabetsky, E., T.A. Amador, R.R. Albuquerque, D.S. Nunes and C. Carvalho Ado, 1995. Analgesic activity of psychotria colorata (Willd.ex R. and S.). Muell. Arg. Alkaloids. J. Ethnopharmacol., 48: 77-83. DOI: 10.1016/0378-8741(95)01287-N

21. Pal, S., T. Sen and A.K. Chaudhuri, 1999. Neuropsychopharmacological profile of the methanolic fraction of bryophyllum pinnatum leaf extract. J. Pharm. Pharmacol., 51: 313-18. DOI: 10.1211/0022357991772312

22. Ahmed, F., M.H. Hossain, A.A. Rahman and I.Z. Shahid, 2006. Antinociceptive and sedative effects of the bark of cerbera odollam Gaertn. Ori. Pharm. Exp. Med., 6: 344-348. http://www.opem.org/board_pds/content_detail.asp $? \mathrm{idx}=389$ \& volume $=6$ 
23. Ronaldo, A.R., L.V. Mariana, M.T. Sara, B.P.P. Adriana, P. Steve, S.H. Ferreira and Q.C. Fernando, 2000. Involvement of resident macrophages and mast cells in the writhing nociceptive response induced by zymosan and acetic acid in mice. Eur. J. Pharmacol., 387: 111-118. DOI: 10.1016/S00142999(99)00790-6

24. Voilley, N., 2004. Acid-Sensing Ion Channels (ASICs): New targets for the analgesic effects of Non-Steroid Anti-Inflammatory Drugs (NSAIDs). Curr. Drug Targets Inflam. Allerg., 3: 71-79. DOI: $10.2174 / 1568010043483980$

25. Hossain, M.M., M.S. Ali, A. Saha and M. Alimuzzaman, 2006. Antinociceptive activity of whole plant extracts of Paederia foetida. Dhaka Univ. J. Pharm. Sci., 5: 67-69. http://www.pharmadu.net/dujps/Journals/Article_1 4.pdf

26. Parke, D.V. and A. Sapota, 1996. Chemical toxicity and reactive species. Int. J. Occup. Med. Environ. Health, 9: 119-123. http://www.ncbi.nlm.nih.gov/sites/entrez?

27. Brown, J.E. and C.A. Rice-Evans, 1998. Luteolinrich artichoke extract protects low density lipoprotein from oxidation in vitro. Free Rad. Res., 29: 247-255. DOI: 10.1080/10715769800300281

28. Vinson, J.A., Y.A. Dabbagh, M.M. Serry and J. Jang, 1995. Plant flavonoids, especially tea flavonols are powerful antioxidants using an in vitro oxidation model for heart disease. J. Agric. Food Chem., 43: 2800-2802. DOI: 10.1021/jf00059a005

29. Rajnarayana, K., M.S. Reddy, M.R. Chaluvadi and D.R. Krishna, 2001. Biflavonoids classification, pharmacological, biochemical effects and therapeutic potential. Ind. J. Pharmacol., 33: 2-16. http://www.ijp-online.com/article.asp?issn=02537613

30. Rao, M.R., Y.M. Rao, A.V. Rao, M.C. Prabhkar, C.S. Rao and N. Muralidhar, 1998. Antinociceptive and anti-inflammatory activity of a flavonoid isolated from Caralluma attenuate. J. Ethnopharmacol., 62: 63-66. DOI: 10.1016/S03788741(98)00048-8
31. Vanu, M.R., S. Palanivelu and S. Panchanatham, 2006. Immunomodulatory and anti-inflammatory effects of Semecarpus anacardium Linn. Nut milk extract in experimental inflammatory conditions. Biol. Pharm. Bull., 29: 693-700. DOI: 10.1248/bpb.29.693

32. Gil, M.I., F. Ferreres and F.A. Tomás-Barberán, 1999. Effect of postharvest storage and processing on the antioxidant constituents (flavonoids and vitamin C) of fresh-cut spinach. J. Agric. Food Chem., 47: 2213-2217. DOI: 10.1021/jf9812001

33. Kähkönen, M.P., A.I. Hopia, H.J. Vuorela, J.P. Rauha, K. Pihlaja, T.S. Kujala and M. Heinonen, 1999. Antioxidant activity of plant extracts containing phenolic compounds. J. Agric. Food Chem., 47: 3954-3962. DOI: 10.1021/jf9901461

34. Moncada, A., R.M.J. Palmer and E.A. Higgs, 1991. Nitric oxide: Physiology, pathophysiology and pharmacology. Pharmacol. Rev., 43: 109-142. http://pharmrev.aspetjournals.org/cgi/reprint/43/2/109

35. Tanaka, M., C.W. Kuie, Y. Nagashima and T. Taguchi, 1988. Applications of antioxidative Maillard reaction products from histidine and glucose to sardine products. Nippon Suisan Gakkaishi, 54: 1409-1414.

http://www.journalarchive.jst.go.jp/english/jnlabstr act_en

36. Duh, P.D., Y.Y. Tu and G.C. Yen, 1999. Antioxidant activity of the aqueous extract of harng Jyur (Chrysanthemum morifolium Ramat). LebensmittelWissenschaft und Technol., 32: 269-277. http://www.ingentaconnect.com/content/ap/fs/1999 /00000032/00000005/art00548

37. Soares, J.R., T.C.P. Dinis, A.P. Cunha and L.M. Almeida, 1997. Antioxidant activities of some extracts of thymus zygis. Free Rad. Res., 26: 469-478. DOI: 10.3109/10715769709084484 